\title{
Growth Effects of Combined Application of Cow Manure And Inorganic Nitrogen Fertilizer on Growth, Yield and Nitrogen Uptake of Black Rice
}

\author{
Marwanto Marwanto $^{1 *}$, Nasiroh ${ }^{1}$, Bambang Gonggo Mucitro ${ }^{2}$, Merakati Handajaningsih ${ }^{1}$ \\ ${ }^{1}$ Department of Agroecotechnology, Faculty of Agriculture, University of Bengkulu, Bengkulu, Indonesia \\ ${ }^{2}$ Department of Soil Science, Faculty of Agriculture, University of Bengkulu, Bengkulu, Indonesia \\ WR Supratman St, Kandang Limun, Bengkulu 38371, Indonesia
}

\author{
ARTICLE INFO \\ Keywords: \\ integrated nutrient management \\ soil chemical property \\ Nitrogen uptake \\ combined fertilizer application \\ black rice

\section{Article history:} \\ Received: Aug 04, 2018 \\ Accepted: Dec 20, 2018 \\ *Corresponding author: \\ E-mail: marwanto@unib.ac.id
}

\begin{abstract}
The beneficial effects of manure on soil properties, growth, and crop productivity have promoted its use for replacing the application of $\mathrm{N}$ fertilizer. However, it is not well understood to what extent $\mathrm{N}$ fertilizer was able to be substituted by cow manure. Accordingly, this pot experiment aimed to compare the effect of inorganic $\mathrm{N}$ fertilizer application alone with that of the combined use of inorganic $\mathrm{N}$ fertilizer with cow manure based on the same amount of total $\mathrm{N}$ on growth parameters, yield attributes, and nitrogen $(\mathrm{N})$ uptake of black rice. The experiment was conducted under a screen house condition in Agriculture Faculty, Bengkulu University located at 15 meters altitude above sea level during the summer season of 2015 . There were six treatments viz. $\mathrm{T}_{1}=$ $100 \% \mathrm{~N}$ from urea $+0 \% \mathrm{~N}$ from cow manure $(0.52 \mathrm{~g} \mathrm{~N}+0.00 \mathrm{~g}$ cow manure) pot $^{-1}, \mathrm{~T}_{2}=80 \% \mathrm{~N}$ from urea $+20 \% \mathrm{~N}$ from cow manure $(0.42 \mathrm{~g} \mathrm{~N}+9.55 \mathrm{~g}$ cow manure) pot $^{-1}, \mathrm{~T}_{3}=60 \% \mathrm{~N}$ from urea $+40 \% \mathrm{~N}$ from cow manure $(0.31 \mathrm{~g}$ $\mathrm{N}+19.10 \mathrm{~g}$ cow manure) pot $^{-1}, \mathrm{~T}_{4}=40 \% \mathrm{~N}$ from urea $+60 \% \mathrm{~N}$ from cow manure $\left(0.21 \mathrm{~g} \mathrm{~N}+28.65 \mathrm{~g}\right.$ cow manure) pot $^{-1}, \mathrm{~T}_{5}=20 \% \mathrm{~N}$ from urea $+80 \%$ $\mathrm{N}$ from cow manure $(0.10 \mathrm{~g} \mathrm{~N}+38.20 \mathrm{~g}$ cow manure $)$ pot $^{-1}$, and $\mathrm{T}_{6}=0 \% \mathrm{~N}$ from urea $+100 \% \mathrm{~N}$ from cow manure $(0.00 \mathrm{~g} \mathrm{~N}+47.75 \mathrm{~g}$ cow manure $)$ pot $^{-}$ 1 . The amount of inorganic $\mathrm{N}$ fertilizer in the form of urea and cow manure applied was calculated based on the recommended rate of $115.00 \mathrm{~kg} \mathrm{ha}^{-1}$ for $\mathrm{N}$ fertilizer and 10.50 ton $\mathrm{ha}^{-1}$ for cow manure. These treatments were arranged in a Completely Randomized Design and repeated three times. The results showed that the treatments significantly $(\mathrm{P} \leq 0.005)$ affected growth parameters as measured by plant height, the number of leaves, fresh shoot weight, fresh root weight, dry shoot weight, dry root weight, yield attributes as determined by the total number of tillers, the total number productive tillers, grain yield per pot, and $\mathrm{N}$ uptake. The highest values for all these variables were obtained in the treatment receiving recommended rate of urea only $(100 \% \mathrm{~N}$ from urea $+0 \% \mathrm{~N}$ from cow manure as equivalence) and the lowest in the treatment receiving a $100 \% \mathrm{~N}$ from cow manure $(0 \% \mathrm{~N}$ from urea $+100 \% \mathrm{~N}$ from cow manure). However, combined treatments of cow manure and inorganic $\mathrm{N}$ fertilizer such as $80 \% \mathrm{~N}$ from urea $+20 \% \mathrm{~N}$ from cow manure, $60 \%$ $\mathrm{N}$ from urea $+40 \% \mathrm{~N}$ from cow manure $40 \% \mathrm{~N}$ from urea $+60 \% \mathrm{~N}$ from cow manure showed a parity statistically with the treatment receiving $100 \% \mathrm{~N}$ from urea only in maintaining the values for all these variables. Overall, the combined use of inorganic $\mathrm{N}$ fertilizer (urea) and cow manure as an equivalence promoted growth and yield of black rice by improving $\mathrm{N}$ uptake.
\end{abstract}

\section{INTRODUCTION}

Rice (Oryza sativa L.) is one of the most important cereal crops providing 50 to $85 \%$ of daily energy source (FAO, 2008). White, red and black rice are the three most common types of rice. The black rice was known as a type of the rice species Oryza sativa L. possessing colored pericarp layer (other than white and red). The dark purple color in its pericarp layers is due to high anthocyanin content (Takashi et al., 2001). There are a total of more than 200 types of black rice widely grown in South, and Southeast
Asian counties such a China, Sri Lanka, India, Indonesia, and Thailand (Kong et al., 2008) with China considered the highest black rice production country. The black rice was grown for its high nutritional contents. It contains a higher level of proteins, minerals such as Fe, $\mathrm{Zn}, \mathrm{Mn}, \mathrm{P}$, antioxidants, and polyphenols than white rice (Yodmanee et al., 2011). These nutritional substances have good impacts on human health when included in their diet (Asem et al., 2015).

Different agricultural practices are applied to increase and optimize rice yield, and one of them is fertilizer application. Urea is a type of inorganic fertilizer widely

ISSN: $1410-3354$ / e-ISSN:2615-7136

Cited this as: Marwanto, Nasiroh, B.G. Mucitro and M. Handajaningsih. 2018. Effects of combined application of cow manure and inorganic nitrogen fertilizer on growth, yield and nitrogen uptake of black rice . Akta Agrosia 21(2):55-60. 
used by farmers for obtaining higher rice productivity. Unfortunately, the applied urea cannot entirely be absorbed by rice roots. According to Werner (2013), N nutrients in urea fertilizer can be utilized only about $10 \%-20 \%$ of the total $\mathrm{N}$ fertilizer added. They further stated that the loss of $\mathrm{N}$ in the soil could be attributed to NO3-leaching, evaporation, denitrification of $\mathrm{NO}_{3}$ - to $\mathrm{N}_{2}$, volatilization of $\mathrm{NH}_{4}^{+}$to $\mathrm{NH}_{3}^{-}$, clay mineral fixation, and soil microorganism used. Rahman and Zhang (2018) reported that excessive use of urea fertilizers could lead to soil degradation and environmental pollution, the decline in crop production and reduced soil biological activity. Therefore, it is necessary to overcome the negative impacts of continuous and excessive use of urea by applying an alternatively available source of $\mathrm{N}$ such as organic manures. Better crop yields due to organic manure application were reported by Tayebeh et al. (2010) and Mohammadi et al. (2013).

Compared to inorganic $\mathrm{N}$ fertilizer, organic manure releases its nutrients to the plants slowly, and these nutrients were not able to be absorbed by plant roots instantly. The slow release of its nutrients (especially $\mathrm{N}$ ) was evident due to slow nutrient mineralization from applied compost (Eghball, 2000). Consequently, the plants have a little access to absorb the required amount of nutrients in the critical yield-forming period. One of the solutions to these problems is to implement integrated nutrient management (Khan et al., 2006). The integrated nutrient management means that inorganic and organic fertilizers were applied together in combination with the purpose mainly to reduce the use of urea fertilizer and replace it with organic $\mathrm{N}$ from organic materials such as compost. Better crop yields due to such combination were reported by Seran et al. (2010) and Agegnehu et al. (2014) in onion and Tayebeh et al. (2010) in wheat. Seran et al. (2010) concluded that application of half-fold of recommended inorganic fertilizers combined with compost at 4 ton $\mathrm{ha}^{-1}$ resulted in better onion yield.

Similarly, use of half rate of recommended $\mathrm{N}$ and $\mathrm{P}$ combined with half rate of recommended manure as inorganic equivalence gave yield advantages of about $129 \%$ compared to the control treatment (Agegnehu et al., 2014). Tabeyeh et al. (2010) also reported that combined application of inorganic and organic fertilizers maintained grain wheat yield and further stated that implementation of organic fertilizer was able to substitute $30 \%$ of the recommended $\mathrm{N}$ fertilizer. The same integrated nutrient management has not been tested on black rice. Therefore, the present study aimed to determine the combined application rate of inorganic $\mathrm{N}$ fertilizer and cow manure as inorganic $\mathrm{N}$ equivalence best supporting black rice growth and grain yield.

\section{MATERIALS AND METHODS}

This pot experiment was conducted under a screen house condition in Agriculture Faculty, Bengkulu University located at 15 meters altitude above sea level during the summer season of 2017. This study used a Completely Randomized Design (CRD) with a single factor to lay out the treatments. The treatments consisted of six combined application of inorganic $\mathrm{N}$ fertilizer (urea) with cow manure as inorganic $\mathrm{N}$ equivalence, and each treatment was replicated five times.

They were $\mathrm{T}_{1}(100 \% \mathrm{~N}$ from urea $+0 \% \mathrm{~N}$ from cow

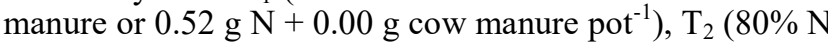
from urea $+20 \% \mathrm{~N}$ from cow manure or $0.42 \mathrm{~g} \mathrm{~N}+9.55$ g cow manure pot $\left.^{-1}\right), \mathrm{T}_{3}(60 \% \mathrm{~N}$ from urea $+40 \% \mathrm{~N}$ from cow manure or $0.31 \mathrm{~g} \mathrm{~N}+19.10 \mathrm{~g}$ cow manure pot $\left.{ }^{-1}\right), \mathrm{T}_{4}$ $(40 \% \mathrm{~N}$ from urea $+60 \% \mathrm{~N}$ from cow manure or $0.21 \mathrm{~g} \mathrm{~N}$
$+28.65 \mathrm{~g}$ cow manure pot $\left.^{-1}\right), \mathrm{T}_{5}(20 \% \mathrm{~N}$ from urea $+80 \%$ $\mathrm{N}$ from cow manure or $0.10 \mathrm{~g} \mathrm{~N}+38.20 \mathrm{~g}$ cow manure pot $\left.{ }^{-1}\right)$, and $\mathrm{T}_{6}(0 \% \mathrm{~N}$ from urea $+100 \% \mathrm{~N}$ from cow manure or $0.00 \mathrm{~g} \mathrm{~N}+47.75 \mathrm{~g}$ cow manure pot ${ }^{-1}$ ). The amount of $\mathrm{N}$ fertilizer in the form of urea and cow manure applied was calculated based on the recommended rate of $115.00 \mathrm{~kg}$ ha ${ }^{1}$ for $\mathrm{N}$ fertilizer and 10.50 ton $\mathrm{ha}^{-1}$ for cow manure. The amount of $\mathrm{N}$ fertilizer in the form of urea and cow manure applied was calculated based on the recommended rate of $115.00 \mathrm{~kg} \mathrm{ha}^{-1}$ for $\mathrm{N}$ fertilizer and 10.50 ton ha ${ }^{-1}$ for cow manure. Recommended basal fertilizers at $72 \mathrm{~kg} \mathrm{P}_{2} \mathrm{O}_{5}$ ha-1 and $60 \mathrm{~kg} \mathrm{~K} \mathrm{~K}_{2} \mathrm{O}$ ha-1 were also applied on each treatment. Cow manure used in this study had a water content of $9.63 \%, \mathrm{~N}$ nutrient content of $1.19 \%$, and $\mathrm{C}$-organic of $14.07 \%$ (Table 1).

Local black rice variety 'Mansur' from Bali Province, Indonesia was used in this study. Before nursery sowing, one hundred seeds were taken and subjected to laboratory germination test under favorable conditions using a rolled paper towel for initial seed quality test. The initial quality of the seed was $90 \%$. The seeds were then sown in a nursery box filled with topsoil according to the recommended methods for 15 days.

This study used $10 \mathrm{~kg}$ polybag as planting media. Each polybag was filled with $10 \mathrm{~kg}$ of soil (dry weight basis). Soil chemical properties of the study site and chemical properties of cow manure before planting were determined with the method as outlined by Jackson (1958). The soil was collected from topsoil at $15 \mathrm{~cm}$ depth and sieved. Two days before transplanting, cow manure at amount mentioned in each treatment was added to the soil and mixed thoroughly. At the same time, a full dose of basal fertilizers at $72 \mathrm{~kg} \mathrm{P}_{2} \mathrm{O}_{5} \mathrm{ha}^{-1}$ and $60 \mathrm{~kg} \mathrm{~K}_{2} \mathrm{O} \mathrm{ha}^{-1}$ and a half dose of $\mathrm{N}$ in the form of urea was also amended. The remaining $50 \% \mathrm{~N}$ was applied at the beginning of the panicle formation period. The soil in each polybag was maintained in wet condition throughout the growing period at $5 \mathrm{~cm}$ of standing water except at harvesting period. A 15 days old rice seedling was then transplanted manually in each polybag. Weeding was conducted manually as needed. Insecticides such as chlorpyrifos at $530 \mathrm{~g} \mathrm{~L}^{-1}$ and Sipermetrin at $55 \mathrm{~g} \mathrm{~L}^{-1}$ at a dose of $2 \mathrm{ml} \mathrm{L}^{-1}$ water were used to control the pest. Rice grain was harvested was at 103 days after transplanting when $90 \%$ rice panicle was yellow, and rice pericarp was dark in color.

Observations were recorded on growth and yield attributes. Plant height $(\mathrm{cm})$ was measured from the base of the stem to the highest leaf using a meter. The measurements were made once a week from 7 days after transplanting (DAT) to initial flowering stage. Shoot, and fresh root weight $(\mathrm{g})$ was measured by weighing a fresh shoot and clean root separately at initial flowering stage. Shoot and root dry weight (g) was measured separately after the shoot and root were oven-dried at $72^{\circ} \mathrm{C}$ until their constant weight was attained. A total number of tillers was obtained by counting all tillers at primordial phase. Some productive tillers were measured by counting all productive tillers at initial flowering stage. The dry weight of grain per pot was obtained by weighing oven-dried grain per pot at $72^{\circ} \mathrm{C}$ until their constant weight was attained. The nitrogen content of dried leaf $(\%)$ was measured on $0.2 \mathrm{~g}$ sample of flag leaf by the Kjeldahl method of $96 \%$ $\mathrm{H}_{2} \mathrm{SO}_{4}$ hot digestion (Jackson, 1958). Nitrogen uptake was determined by multiplying $\mathrm{N}$ leaf tissue content and shoots dry weight or with the following formula:

Nitrogen uptake $\left(g_{\text {pot }}^{-1}\right)=\frac{N \text { concentration }(\%) x \text { dry wieght }\left(g_{\text {pot }}^{-1}\right)}{}$ 100

Data from the observations were analyzed statistically using analysis of variance (ANOVA) at the level of $5 \%$. 
The mean values of the treatments were compared with Least Significant Difference (LSD) at the level of 5\% (Gomez and Gomes, 1984).

\section{RESULTS AND DISCUSSION}

\section{Soil Analysis}

Based on the results of soil analysis, the soil used as a planting medium has $\mathrm{pH}\left(\mathrm{H}_{2} \mathrm{O}\right) 3.96$, organic $\mathrm{C} 2.43 \%$ and $\mathrm{N}$-total $1.01 \%$ (Table 1). These low soil characteristics were not supportive of the growth of rice plants. Rice grows well at a soil $\mathrm{pH}$ ranging from 5.5 to 7.5 (FAO, 2006) and requires $\mathrm{N}$ nutrients of $92 \mathrm{~kg} \mathrm{~N} \mathrm{ha}^{-1}$ (Permentan, 2007). Therefore, it is justified to add the combination of inorganic $\mathrm{N}$ and organic sources of nutrients to promote maximum growth and yield of black rice. Inorganic $\mathrm{N}$ source of nutrient used was urea because its nutrient is readily available for plants in a short time. An organic source of nutrient utilized was cow manure because it can improve soil physicochemical properties.

Table 1. Soil chemical properties of the study site and chemical properties of cow manure before planting.

\begin{tabular}{lcc}
\hline $\begin{array}{l}\text { Chemical Proper- } \\
\text { ties }\end{array}$ & \multicolumn{2}{c}{ Parameters } \\
\cline { 2 - 3 } & Soil & Cow manure \\
\hline $\mathrm{pH}\left(\mathrm{H}_{2} \mathrm{O}\right)$ & 3,96 & \\
$\mathrm{pH}(\mathrm{KCl})$ & 3,12 & \\
$\mathrm{C}-$-organic $(\%)$ & 2,43 & 14,07 \\
N-total $(\%)$ & 1,01 & 1,19 \\
Soil moisture & - & 9.63 \\
content $(\%)$ & & \\
\hline
\end{tabular}

\section{Growth Parameters}

The analysis of variance revealed that the effect of the combined application of urea (inorganic $\mathrm{N}$ fertilizer) and cow manure as inorganic $\mathrm{N}$ equivalence was significant $(\mathrm{P}<0.05)$ on vegetative growth of black rice as measured by plant height, leaf number, and biomass production as evaluated by fresh and dry weight of shoot and root (Table 2). The highest plant height was observed in $\mathrm{T}_{1}$ (control treatment), a treatment receiving only recommended rate of urea without cow manure addition. However, the plant height in this treatment was not statistically different from that in other treatments $\left(\mathrm{T}_{2}, \mathrm{~T}_{3}\right.$, $\mathrm{T}_{4}$, and $\mathrm{T}_{5}$ ) when both urea and cow manure was applied in a combination. This result implies that when urea and cow manure was applied together in a combination, a decrease in the proportion of urea in the combination did not significantly reduce plant height when replaced by an increase in the proportion of applied cow manure. Even, a combined application of $20 \% \mathrm{~N}$ from urea with $80 \% \mathrm{~N}$ from cow manure ( $\mathrm{T}_{5}$ treatment) was still able to maintain the same plant height as $\mathrm{T}_{1}$ treatment. It is obvious that up to $80 \%$ of the required $\mathrm{N}$ nutrient from urea could be substituted by inorganic $\mathrm{N}$ nutrient from compost as equivalence without having a negative effect on plant height. Further decrease in the proportion of urea in the combination such as $\mathrm{T}_{6}$ (treatment receiving an only organic source of nutrient from cow manure and no urea) reduced plant height significantly to the lowest value. Plant height in this treatment was almost $21 \%$ lower than that in the other treatments.

The highest leaf number was noticed in $\mathrm{T}_{1}$ (control treatment); however, the leaf number in this treatment was not statistically different with $\mathrm{T}_{2}, \mathrm{~T}_{3}$, and $\mathrm{T}_{4}$ treatments (Table 2). This result suggests that inorganic $\mathrm{N}$ fertilizer from urea was able to be substituted with cow manure as organic $\mathrm{N}$ equivalence until $60 \%$ of the required inorganic $\mathrm{N}$ fertilizer without causing the negative effect on some leaves. On the contrary, treatments receiving $20 \%$ of inorganic $\mathrm{N}$ combined with $80 \%$ of organic fertilizer as cow manure $\left(\mathrm{T}_{5}\right)$ and $100 \%$ of organic fertilizer $\left(\mathrm{T}_{6}\right)$ showed a significant decrease in leaf number as compared to the previous treatments $\left(T_{1}, T_{2}, T_{3}\right.$, and $\left.T_{4}\right)$. The lowest leaf number was recorded in $\mathrm{T}_{5}$ and $\mathrm{T}_{6}$ treatments. Leaf number in these two treatments was twice lower than that in $T_{1}, T_{2}, T_{3}$, and $T_{4}$ treatments even though leaf number in $\mathrm{T}_{5}$ and $\mathrm{T}_{6}$ treatments were not statistically different.

The analysis of variance showed that the effect of combined application of urea (inorganic $\mathrm{N}$ fertilizer) and cow manure as inorganic $\mathrm{N}$ equivalence was significant $(\mathrm{P}$ $<0.05)$ on black rice biomass production as measured by shoot fresh weight (SFW), shoot dry weight (SDW), root fresh weight (RFW), and root dry weight (RDW). Combined manure compost with inorganic $\mathrm{N}$ fertilizer $\left(\mathrm{T}_{3}\right)$ showed significantly and the highest RFW and RDW as shown in Table 2. Data in Table 2 also displayed that $\mathrm{T}_{2}$ demonstrated the highest SFW; however, this treatment showed parity statistically with $\mathrm{T}_{1}$ and $\mathrm{T}_{3}$. The SFW in $\mathrm{T}_{1}$, $\mathrm{T}_{2}$, and $\mathrm{T}_{3}$ treatments was superior than that in $\mathrm{T}_{4}, \mathrm{~T}_{5}$, and $\mathrm{T}_{6}$ by $35.00 \mathrm{~g}$ or $15 \%$ over $\mathrm{T}_{4}$, by $61.66 \mathrm{~g}$ or $32.17 \%$ over $\mathrm{T}_{5}$, and $101.66 \mathrm{~g}$ or $67.03 \%$ over $\mathrm{T}_{6}$, respectively. The lowest SFW was noted in $\mathrm{T}_{6}$ (treatment receiving an only organic source of nutrient from cow manure and no urea). The highest shoot dry weight (SDW) was recorded in $\mathrm{T}_{1}$ (control treatment) or treatment only receiving inorganic $\mathrm{N}$ fertilizer. Even though, SDW in $\mathrm{T}_{2}, \mathrm{~T}_{3}$, and $\mathrm{T}_{4}$ (treatments receiving combined manure compost with inorganic $\mathrm{N}$

Table 2. Effects of the integrated application of inorganic $\mathrm{N}$ fertilizer and cow manure as $\mathrm{N}$ organic equivalence on growth parameters of black rice.

\begin{tabular}{cccccccc}
\hline & & \multicolumn{7}{c}{ Growth parameters } \\
\cline { 3 - 7 } No & Treatment & $\begin{array}{c}\text { Plant } \\
\text { Height } \\
(\mathrm{cm})\end{array}$ & $\begin{array}{c}\text { Leaf } \\
\text { Number }\end{array}$ & $\begin{array}{c}\text { Shoot Fresh } \\
\text { Weight } \\
(\mathrm{g})\end{array}$ & $\begin{array}{c}\text { Root Fresh } \\
\text { Weight } \\
(\mathrm{g})\end{array}$ & $\begin{array}{c}\text { Shoot Dry } \\
\text { Weight }(\mathrm{g})\end{array}$ & $\begin{array}{c}\text { Root Dry } \\
\text { Weight } \\
(\mathrm{g})\end{array}$ \\
\hline 1 & $\mathrm{~T}_{1}$ & $83,33 \mathrm{a}$ & $114,17 \mathrm{a}$ & $228,33 \mathrm{ab}$ & $190,00 \mathrm{~b}$ & $52,43 \mathrm{a}$ & $61,98 \mathrm{~b}$ \\
2 & $\mathrm{~T}_{2}$ & $85,17 \mathrm{a}$ & $107,27 \mathrm{a}$ & $253,33 \mathrm{a}$ & $203,33 \mathrm{~b}$ & $52,02 \mathrm{a}$ & $47,80 \mathrm{c}$ \\
3 & $\mathrm{~T}_{3}$ & $86,64 \mathrm{a}$ & $98,94 \mathrm{a}$ & $228,33 \mathrm{ab}$ & $236,67 \mathrm{a}$ & $50,76 \mathrm{ab}$ & $83,49 \mathrm{a}$ \\
4 & $\mathrm{~T}_{4}$ & $85,11 \mathrm{a}$ & $90,50 \mathrm{a}$ & $218,33 \mathrm{~b}$ & $211,67 \mathrm{ab}$ & $46,86 \mathrm{ab}$ & $49,02 \mathrm{c}$ \\
5 & $\mathrm{~T}_{5}$ & $89,00 \mathrm{a}$ & $51,17 \mathrm{~b}$ & $191,67 \mathrm{c}$ & $125,00 \mathrm{c}$ & $42,52 \mathrm{bc}$ & $33,47 \mathrm{~d}$ \\
6 & $\mathrm{~T}_{6}$ & $71,22 \mathrm{~b}$ & $47,27 \mathrm{~b}$ & $151,67 \mathrm{~d}$ & $116,67 \mathrm{c}$ & $33,60 \mathrm{c}$ & $26,07 \mathrm{~d}$ \\
\hline
\end{tabular}

Means not followed with the same letter in each column differ statistically at $\mathrm{P}<0.05$ according to the Least Significant Different 
fertilizer showed parity with control treatment $\left(\mathrm{T}_{1}\right)$ as revealed in Table 2. The lowest SDW was observed in $T_{6}$ treatment; however, this treatment was statistically at par with $\mathrm{T}_{5}$ treatment. Overall, treatments receiving inorganic $\mathrm{N}$ fertilizer in combination with cow manure $\left(\mathrm{T}_{2}, \mathrm{~T}_{3}\right.$, and $\mathrm{T}_{4}$ ) were superior over treatment receiving cow manure only $\left(\mathrm{T}_{6}\right)$ in producing above ground plant dry matter by $13.26-18.42 \mathrm{~g}$ or $39.46-54.82 \%$.

\section{Yield Components}

The yield components of black rice in term of some productive tillers and grain dry weight per pot were significantly affected by the different source of nutrients (Table 3). Treatments receiving combined application of inorganic and organic source of nutrient $\left(\mathrm{T}_{2}, \mathrm{~T}_{3}\right.$, and $\left.\mathrm{T}_{4}\right)$ produced more effective tillers and grain dry weight per pot than that receiving only organic source of nutrient $\left(\mathrm{T}_{6}\right)$ by about five effective tillers or $72.03 \%$ for number of effective tillers and $11.29 \mathrm{~g} /$ pot or $144 \%$ for grain dry weight per pot. However, these three treatments were significantly at par with treatment receiving an only inorganic source of nutrient (control treatment or $\mathrm{T}_{1}$ ).

\section{Nitrogen (N) Uptake}

The result of the analysis of variance showed that $\mathrm{N}$ uptake was significantly influenced by combination application of inorganic $\mathrm{N}$ fertilizer and cow manure (Table 3). The highest $\mathrm{N}$ uptake was noted in $\mathrm{T}_{1}$ treatment where only inorganic $\mathrm{N}$ fertilizer was applied. However, this treatment showed parity statistically with $T_{2}$ and $T_{3}$ treatments where cow manure and inorganic $\mathrm{N}$ fertilizers were used in a combination. After $T_{1}, T_{2}$, and $T_{3}$ treatments, the high value of $\mathrm{N}$ uptake was recorded in $\mathrm{T}_{4}$ where this treatment was statistically at par with $\mathrm{T}_{5}$. The lowest amount of $\mathrm{N}$ uptake was observed in $\mathrm{T}_{6}$ where only cow manure was applied. Above all, $\mathrm{N}$ uptake gained in response to the combined use of manure compost with inorganic $\mathrm{N}$ fertilizer was higher than that obtained in response to only cow manure application by around $40.8-73.3 \%$.

\section{Discussion}

The combined use of cow manure and urea promoted black rice growth performances as expressed by plant height and leaf number. The more significant effect of the combined application system of organic and inorganic source of nutrient than the single source of nutrient treatment were also reported by Vo and Wong (2015) in muskmelon, Adekiya and Agbede (2009) in tomato, Khoshgoftarmanesh and Eshghizadeh (2011) in corn, and Gangmei and George (2017) in black rice. Such combination brought about readily available nutrient contributed by inorganic fertilizer and an enhanced soil organic matter, improved soil structure and buffering capacity mainly provided by organic fertilizer (Yadaf et al., 2013). The improved soil properties (even though not recorded in this study) in turn promoted the easily absorption of water and usage of nutrient elements for important physiological processes (Place et al., 2003) and would be a reason towards high $\mathrm{N}$ uptake for treatments receiving combined use of manure compost with inorganic $\mathrm{N}$ fertilizer in this study. High $\mathrm{N}$ uptake improved dry matter accumulation as a result of better growth and development of rice plant (Sing and Jain, 2000). Dry biomass production measured by shoot and dry root weight in this study showed a similar trend, and the result of this study was in line with that reported by Sing and Jain (2000). According to Kiniry et al. (2001), dry matter production in rice was dependent on intercept photosynthetically active radiation. Low $\mathrm{N}$ concentration due to low $\mathrm{N}$ uptake caused a decrease in radiation use efficiency and subsequently lower biomass production of rice (Sinclair and Sheehy, 1999). The result of this study showed that low $\mathrm{N}$ uptake was observed in $\mathrm{T}_{6}$ treatment with the lowest dry matter accumulation. Thus, this study was in line with the result reported by Sinclair and Sheehy (1999).

At the cellular level, the synergistic effect of combined use of organic and inorganic fertilizers initially stimulates cell division, cell growth, and finally multiplication of leaves as reported by Abou-Hossain et al. (2003). Zadeh (2014) also reported that cow manure not only behaved as a source of $\mathrm{N}$ and other nutrients but also improved the efficiency of applied N. Meanwhile, the lowest crop performance in the treatment receiving just organic fertilizer with zero inorganic fertilizer $\left(\mathrm{T}_{6}\right)$ was primarily due to slow nutrient release characteristic possessed by organic fertilizer. It means that organic fertilizer such as cow manure liberated its nutrients slowly and consequently these nutrients could not be readily available to the plants in the crucial biomass-forming period. As a result, cow manure could not promote crop growth and yield within a short period due to its low nutrient status as compared to inorganic $\mathrm{N}$ fertilizer (Negassa et al., 2007). This result was in line with the report of Daniel et al. (2008).

The maximum effective tillers number and grain dry weight per pot was recorded as a result of cow manure application along with inorganic $\mathrm{N}$ fertilizer. This was probably due to increasing the available $\mathrm{N}$ through inorganic fertilizer along with improved the physical, chemical, and biological properties of soil (although not all these soil properties recorded in this present study) through cow manure (Yourtchi et al., 2013). These synergistic effects, in turn, promoted more active cell division, an increase in photosynthetic efficiency and water intake to the cells, contributing to the improvement of yield parameters (Mohammadi et al., 2013). The enhancement in

Table 3. Effects of combined application of inorganic $\mathrm{N}$ fertilizer and cow manure as $\mathrm{N}$ organic equivalence on yield parameters and nitrogen $(\mathrm{N})$ uptake of black rice

\begin{tabular}{cccccc}
\hline \multirow{2}{*}{ No } & Treatment & \multicolumn{3}{c}{ Yield parameters } & N Uptake \\
\cline { 3 - 4 } & & $\begin{array}{c}\text { Total Number of } \\
\text { Tillers }\end{array}$ & $\begin{array}{c}\text { Number of Effec- } \\
\text { tive Tillers }\end{array}$ & $\begin{array}{c}\text { Grain Dry Weight } \\
(\mathrm{g} / \mathrm{pot})\end{array}$ & $19,12 \mathrm{a}$ \\
\hline 1 & $\mathrm{~T}_{1}$ & $25,67 \mathrm{a}$ & $12,33 \mathrm{a}$ & $18,36 \mathrm{a}$ & $2.14 \mathrm{a}$ \\
2 & $\mathrm{~T}_{2}$ & $22,67 \mathrm{abc}$ & $11,67 \mathrm{a}$ & $22,95 \mathrm{a}$ & $2.10 \mathrm{a}$ \\
3 & $\mathrm{~T}_{3}$ & $23,67 \mathrm{ab}$ & $11,33 \mathrm{a}$ & $16,02 \mathrm{a}$ & $1.77 \mathrm{~b}$ \\
4 & $\mathrm{~T}_{4}$ & $19,67 \mathrm{bc}$ & $9,67 \mathrm{a}$ & $9,11 \mathrm{~b}$ & $1.61 \mathrm{~b}$ \\
5 & $\mathrm{~T}_{5}$ & $19,67 \mathrm{bc}$ & $8,33 \mathrm{ab}$ & $7,82 \mathrm{~b}$ & $1.20 \mathrm{c}$ \\
6 & $\mathrm{~T}_{6}$ & $17,67 \mathrm{c}$ & $6,33 \mathrm{~b}$ &
\end{tabular}

Means not followed with the same letter in each column differ statistically at $\mathrm{P}<0.005$ according to the Least Significant Different 
yield parameters demonstrated in this study as a result of the combined application of cow manure and inorganic $\mathrm{N}$ fertilizer agreed with the report of Agegnehu et al. (2014).

\section{CONCLUSION}

It is clear from the results of this study that combined application of cow manure and inorganic $\mathrm{N}$ fertilizer promoted greater growth, yield, and $\mathrm{N}$ uptake of black rice than the single application of cow manure. About $40-$ $80 \%$ of the recommended $\mathrm{N}$ fertilizer could be replaced by cow manure as $\mathrm{N}$ inorganic equivalence without inhibiting growth, yield, and $\mathrm{N}$ uptake of black rice.

\section{REFERENCES}

Abou-Hossain , S.D., T. El-Shorbagy, A.F. Abou-Hadid, and U. El-Behairy. 2003. Effect of cattle and chicken manure with or without mineral fertilizers on tuber quality and yield of potato crops. ISHS Acta Horticulturea 608:95-100.

Adekiya, A.O. and T.M. Agbede. 2009. Growth and yield of tomato (Lycopersicon esculentum Mill) as influenced by poultry manure and NPK fertilizer. Emirates J. of Food and Agriculture 21(1):10-20.

Agegnehu, G, C. vanBeek, and M. Bird. 2014. Influence of integrated soil fertility management in wheat and tef productivity and soil chemical properties in the highland tropical environment. Journal of Soil Science and Plant Nutrition 14:532-545.

Asem, I.D., R.K. Imotomba, P.B. Mazumder, and J.M. Laishram. 2015. Anthocyanin content in the black scented rice (Chakhao): its impact on human health and plant defense. Symbiosis 66(1):47-54.

Daniel, M., L.M. Pant, and D. Nigussie. 2008. Effect of integrated nutrient management on the yield of potato and soil nutrient status of Bako, West Shoa. Ethiopian Journal of Natural Resources 10:85-101.

Eghball, B. 2000. Nitrogen mineralization from fieldapplied beef cattle feedlot manure or compost. Soil Science Society of America Journal 64: 2024-2030.

FAO [Food and Agriculture Organization]. 2006. Plant Nutrition and Food Security: A Guide for Integrated Nutrient Management. FAO, Fertilizer and Nutrition Bulletin 16, Rome, Italy.

FAO [Food and Agriculture Organization]. 2008. Food and Agriculture Statistics Global Outlook. Food and Agriculture Organization of the United Nations. Available from: http:/faostat.fao.org/Portals/ Faostat/documents/pdf/world.pdf.

Gangmei, T.P. and P.J. George. 2017. Black rice cv. 'Chakhao Amubi' (Oryza sativa L.) response to organic and inorganic sources of nutrients on growth, yield, and grain protein content. Journal Pharmacognosy and Phytochemistry 6(4):550-555.

Gomez, K.A. and A.A. Gomez. 1984. Statistical Procedures for Agricultural Research ( $2^{\text {nd }}$ ed.). New Delhi, India: International Rice Research Institute, $680 \mathrm{p}$.

Jackson, M.L.1958. Soil Chemical Analysis. Engle Wood Cliffs, New Jersey: Prentice Hall Inc.

Khan, U., B. Mishra, P. Pachauri, and Y. Kumar. 2006. Effect of integrated nitrogen management on yield and nitrogen of irrigated rice (Oryza sativa). Indian Journal of Agricultural Sciences. 76(3):176-180.

Khoshgoftarmanesh, A.H. and H.R. Eshghizadeh. 2011.
Yield response of corn to single and combined application of cattle manure and urea. Communications in Soil Science and Plant Analysis 42(10):1200-1208.

Kiniry, J.R., G. McCauley, Y. Xie, and J.G. Arnold. 2001. Rice parameters are describing crop performance of four US cultivars. Agronomy Journal 93:1354-1361.

Kong, L., Y. Wang, and Y. Cao. 2008. Determination of myo-inositol and D-chiro-inositol in black rice bran by capillary electrophoresis with electrochemical detection. Journal of Food Composition and Analysis 21(6):501-504.

Mohammadi, G.R., A.R. Ajirloo, M.E. Ghobadi, and A. Najaphy. 2013. Effects of non-chemical and chemical fertilizers on potato (Solanum tuberosum L.) yield and quality. Journal of Medicinal Plants Research 7(1):36-42.

Negassa, W., F. Getaneh, A. Deressa, and B. Dinsa. 2007. Integrated use of organic and inorganic fertilizers for maize production. Utilization of diversity in land use systems: Sustainable and organic approaches to meet human needs - a paper presented on International Research on Food Security, Natural Resources Management and Rural Development Conference, Witzenhausen, Germany.

Permentan. 2007. Rekomendasi Pupuk. http:// bengkulu.litbang.pertanian.go.id/ind/images/ dokumen/isi-rekomend-ppk.pdf. Diakses pada tanggal 20 September 2016.

Place, F., C.B. Barret, H.A. Freeman, J.J. Ramisch, and B. Vanlauwe. 2003. Prospects for integrated soil fertility management using organic and inputs: evidence from smallholders African agricultural systems. Food Policy 28:365-378.

Rahman K. M. A. and D. Zhang. 2018. Effects of fertilizer broadcasting on the excessive use of inorganic fertilizers and environmental sustainability. Sustainability 10:1-15

Seran, T.H., S. Srikrishnah, and M.M.Z. Ahamed. 2010. Effect of different levels of inorganic fertilizers and compost as basal application on the growth and yield of onion (Allium cepa L.). The Journal of Agricultural Sciences 5(2): 64-70.

Sinclair, T.R. and J.E. Sheehy. 1999. Erect leaves and photosynthesis in rice. Science 283:1456-1457.

Sing, S. and M.C. Jain. 2000. Growth and yield response of traditional tall and improved semi-tall rice cultivars to moderate and high nitrogen, phosphorus, and potassium levels. Indian Journal of Plant Physiology 5(1):38-46.

Takashi, I., X. Bing, Y. Yoichi, N. Masaharu, and K. Tetsuya. 2001. Antioxidant activity of anthocyanin extract from purple black rice. Journal of Medical Food. 4: 211-218.

Tayebeh, A., A. Abbas, and A.K. Seyed. 2010. Effect of organic and inorganic fertilizers on grain yield and protein banding pattern of wheat. Australian Journal of Crop Science 4(6):384-389.

Vo, M.H. and C.H. Wong. 2015. Effects of manure composts and their combination with inorganic fertilizer on acid soil properties and the growth of muskmelon (Cucumis melo L.). Compost Science \&Utilization 23:117-127.

Werner, A. E. 2013. Nitrogen release, tree uptake, and ecosystem retention in a mid-rotation loblolly pine 
plantation following fertilization with $\mathrm{N}$-enriched enhanced efficiency fertilizers. Master of Science In Forestry. Faculty of the Virginia Polytechnic Institute and State University, USA.

Yadaf, S.K., S. Babu, M.K. Yadaf, K. Sing, and G.S. Yadav. 2013. A review of organic farming for sustainable agriculture in Northern. International Journal of Agronomy 1:1-18.

Yodmanee, S., T.T. Karrila, and P. Pakdeechanuan. 2011. Physical, chemical and antioxidant properties of pigmented rice grown in Southern Thailand.
International Food Research Journal 18(3): 901-906.

Yourtchi, M.S., M.H.S. Hadi, and M.T. Darzi. 2013 Effect of nitrogen fertilizer and vermicompost on vegetative growth, yield and NPK uptake by tuber of potato (Agria CV.). International Journal of Agriculture and Crop Science 5(18):2033-2040.

Zadeh, A.N. 2014. Effects of chemical and biological fertilizer on yield and nitrogen uptake of rice. Journal of Biodiversity and Environmental Sciences $4: 37-46$. 